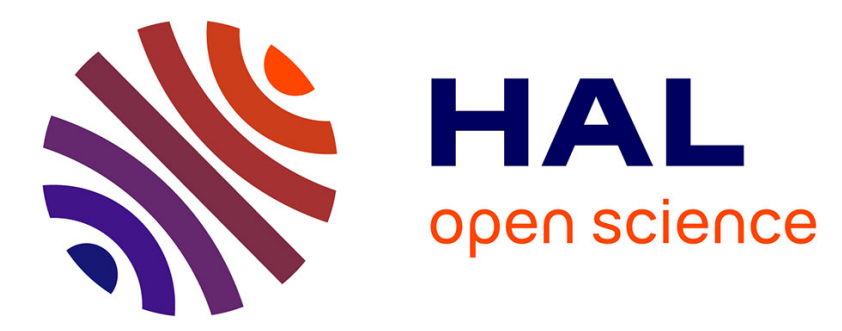

\title{
Cancer-associated adipocytes promotes breast tumor radioresistance.
}

\author{
Ludivine Bochet, Aline Meulle, Sandrine Imbert, Bernard Salles, Philippe \\ Valet, Catherine Muller
}

\section{- To cite this version:}

Ludivine Bochet, Aline Meulle, Sandrine Imbert, Bernard Salles, Philippe Valet, et al.. Cancerassociated adipocytes promotes breast tumor radioresistance.. Biochemical and Biophysical Research Communications, 2011, 411 (1), pp.102-6. 10.1016/j.bbrc.2011.06.101 . inserm-00617636

\section{HAL Id: inserm-00617636 https://www.hal.inserm.fr/inserm-00617636}

Submitted on 29 May 2020

HAL is a multi-disciplinary open access archive for the deposit and dissemination of scientific research documents, whether they are published or not. The documents may come from teaching and research institutions in France or abroad, or from public or private research centers.
L'archive ouverte pluridisciplinaire HAL, est destinée au dépôt et à la diffusion de documents scientifiques de niveau recherche, publiés ou non, émanant des établissements d'enseignement et de recherche français ou étrangers, des laboratoires publics ou privés. 


\title{
Cancer-associated adipocytes promotes breast tumor radioresistance
}

\author{
Ludivine Bochet ${ }^{a, b, c}$, Aline Meulle ${ }^{a, b, c}$, Sandrine Imbert ${ }^{b}$, Bernard Salles ${ }^{a, b}$, Philippe Valet ${ }^{a, c}$, \\ Catherine Muller ${ }^{\mathrm{a}, \mathrm{b}, *}$ \\ ${ }^{a}$ Université de Toulouse, UPS, F-31077 Toulouse Cedex, France \\ ${ }^{\mathrm{b}}$ CNRS, IPBS (Institut de Pharmacologie et de Biologie Structurale), 205 route de Narbonne, BP 64182, F-31077 Toulouse Cedex, France \\ 'Institut National de la Santé et de la Recherche Médicale, INSERM U1048, 1 Avenue du Pr Jean Poulhès, BP 84225, F-31432 Toulouse Cedex, France
}

\section{A R T I C L E I N F O}

\section{Article history}

Received 10 June 2011

Available online 25 June 2011

\section{Keywords:}

Adipocytes

Ionizing radiation

Breast cancer

Radioresistance

Interleukin 6

\begin{abstract}
A B S T R A C T
Mature adipocytes are excellent candidates to influence tumor behavior through heterotypic signaling processes since these cells produce hormones, growth factors, cytokines and other molecules, a heterogeneous group of molecules named adipokines. Using a 2D coculture system, we demonstrate that breast tumor cells previously co-cultivated with mature adipocytes exhibit radioresistance and an earlier and higher increase in the effector kinase Chk1, a phenotype that was associated with decreased cell death as compared to tumor cells grown alone. Interestingly, the adipocytes-induced tumor changes taking place during the coculture time preceding the exposure to IR were sufficient to confer the radioresistant effect. Notorious among the changes brought by adipocytes was the significant increase of IL- 6 expression in tumor cells, whose activity may well account for the observed tumor cell protection from IR toxicity. Indeed, our data confirmed the protective role of this cytokine as tumor cells incubated after irradiation with recombinant IL-6 exhibit an increased in Chk1 phosphorylation and a radioresistant phenotype, thus far recapitulating the effects observed in the presence of adipocytes. Our current study sheds light on a new role of tumor-surrounding adipocytes in fostering a radioresistant phenotype in breast tumors, a finding that might have important clinical implications in obese patients that frequently exhibit aggressive diseases.
\end{abstract}

(c) 2011 Elsevier Inc. All rights reserved.

\section{Introduction}

Radiation therapy (RT) remains an integral component of the current available therapeutic strategies in the treatment of malignant disease. The use of therapeutic doses of ionizing radiation (IR) as a primary sole treatment modality, or in combination with surgery and chemotherapy, results in high rates of loco-regional control in a majority of cancer patients. However, a significant number of patients will experience relapse (for review see [1]) suggesting a possible radioresistant phenotype of tumor cells, and the functional mechanisms behind the radioresistance need to be understanding. IR induces a range of cellular lesions in genomic DNA, thought to be the most important subcellular target molecule. DNA breaks initiates a DNA damage response that coordinates cell-cycle transitions, DNA repair and cell death [2]. The protein kinases Ataxia telangiectasia mutated (ATM) and ATR (ATM and Rad3 related), as well as their downstream substrates Chk1 and Chk2 are central players in determining cellular responses to DNA damage [2]. Although a majority of these lesions are repaired, some unrepaired breaks may be generated and lead to

\footnotetext{
* Corresponding author at: IPBS, 205 route de Narbonne, BP 64182, F-31077 Toulouse Cedex, France. Fax: +33561 175994.

E-mail address: muller@ipbs.fr (C. Muller).
}

chromosomal aberrations and post-mitotic cell death. This mode of cell death is considered to be the major mechanism by which the majority of solid tumors respond to clinical RT [3].

Cancer is a tissue-based disease in which malignant cells interact dynamically with multiple normal cell types such as fibroblasts, adipocytes, infiltrating immune cells and endothelial cells within the context of extra-cellular matrix [4]. Of all cell types present in the microenvironment, adipocytes are probably the least well studied despite the fact that they correspond to one of the most prominent cell type in tissues such as breast [5]. Until recently, adipocytes were mainly considered as an energy storage depot, but there is now clear evidences pointing to the fat tissue as an endocrine organ that produces an heterogeneous group of molecules called adipokines (i.e. hormones, growth factors, cytokines) [6] prone to affect tumor behavior (for review see [7]). We have recently demonstrated that adipocytes participate in a highly complex vicious cycle orchestrated by cancer cells to promote tumor invasion [8]. Invasive cancer cells dramatically impact surrounding adipocytes that exhibit a modified phenotype and specific biological features (delipidation, overexpression of inflammatory cytokines) sufficient to be named "Cancer-Associated Adipocytes (CAAs)" [8]. Several studies have demonstrated that the stroma (including endothelial cells, fibroblasts or macrophages) could cooperate to modulate the response of tumors cells 
to radiation exposure [9-13]. These findings led us to analyze the effect of the adipocyte and tumor cells crosstalk on breast cancer cell response to IR. This issue is of major clinical importance since adiposity is associated with reduced likelihood of survival and increased likelihood of recurrence regardless of the menopausal status even in women with breast cancer that is negative for estrogen receptor (for review see [7]).

\section{Materials and methods}

\subsection{Cell lines and cell culture}

The murine 3T3F442A pre-adipocyte cell line was cultured in DMEM medium supplemented with $10 \%$ of fetal calf serum (FCS). The differentiation was induced by incubating confluent cells in differentiation medium (DMEM supplemented with 10\% FCS plus $50 \mathrm{nM}$ insulin) for up to 14 days as described previously [14]. The term "mature adipocytes" represents cells that have been differentiated for 10-14 days. The human mammary carcinoma cell line SUM159PT (provided by Dr. J. Piette, IGMM, Montpellier, France) was grown in Ham F12 medium complemented with 5\% FCS, $1 \mathrm{mg} / \mathrm{ml}$ hydrocortisone (Sigma) and $0.2 \mathrm{UI} / \mathrm{ml}$ insulin. All cell lines were incubated at $37{ }^{\circ} \mathrm{C}$ with $5 \% \mathrm{CO}_{2}$ in the air. All culture media (Life Tech) were supplemented with antibiotics.

\subsection{Radiation treatment and cell survival determination}

About $5 \times 10^{4}$ SUM159PT cells were seeded in the upper chamber of a Transwell culture system $(0.4 \mu \mathrm{m}$ pore size, Millipore) in the culture medium of adipocytes with or without mature adipocytes in the lower chamber during 3 days. After this period, cocultures were irradiated at the indicated doses using a $130 \mathrm{kV} \mathrm{X-ray}$ machine (Faxitron RX-650), with a dose rate of $0478 \mathrm{~Gy} / \mathrm{min}$ and further incubated during $48 \mathrm{~h}$ in the presence or not of adipocytes. Cell survival after irradiation was determined by clonogenic assay. Tumor cells were trypsinized and plated at low density (500 cells/ $60 \mathrm{~mm}^{2}$ dishes, three dishes per conditions) in complete medium and incubated for 10 days. Colonies were stained with crystal violet and counted under a microscope, with 50 cells as the minimum number to define a surviving colony. In certain conditions, SUM159PT cells were post-incubated after irradiation in the presence of IL-6 (30 ng/ml) (obtained from Peprotech).

\subsection{DAPI staining and post-mitotic cell death detection}

About $5 \times 10^{4}$ SUM159PT cells were plated on coverslips in the upper chamber of the Transwell culture system and co-cultivated or not with mature adipocytes. Three days after, cells were exposed to $5 \mathrm{~Gy}$ followed by $96 \mathrm{~h}$ of incubation. Cells were then washed in PBS and fixed with paraformaldehyde (3.7\%) for $15 \mathrm{~min}$ at room temperature. Coverslips were rinsed three times with PBS and permeabilized 5 min with $0.1 \%$ Triton X-100. Cells were then incubated $15 \mathrm{~min}$ at $37{ }^{\circ} \mathrm{C}$ with $10 \mu \mathrm{g} / \mathrm{ml}$ of DAPI (4,6-diamidino-2phenylindole). Nuclei staining were visualized using a laser scanning spectral confocal microscope (Leica SP2). Post-mitotic dying cells showed abnormal mitosis with the formation of large cells with multiple micronuclei [15]. Percentage of giant multinucleated cells was determined dividing the number of multinucleated cells by the number of total cells counted for each condition (at least 100 cells were counted for each condition).

\subsection{RNA extraction and quantitative RT-PCR ( $q P C R)$}

Total RNAs were extracted using the RNeasy mini kit (Qiagen $\mathrm{GmbH}$ ). Gene expression was analyzed using real time PCR as described previously [16]. The primers to detect IL-6 mRNA were sense primer: 5'-AGGGCTCTTCGGCAAATGTA-3', antisense primer: 5'-GAAGGAATGCCCATTAACAACAA-3' Fluorescence was monitored and analyzed in a GeneAmp 7300 detection system instrument (Applied Biosystems). Analysis of $18 \mathrm{~S}$ ribosomal RNA was performed in parallel using the ribosomal RNA control TaqMan assay kit (Applied Biosystems).

\subsection{Cell extracts and Western blot}

Whole cell extracts and Western blot experiments were performed as previously described [17]. The following antibodies were used: $\beta$ tubulin (clone DM1A) obtained from Neomarkers; pChk1 (Ser345), pChk2 (Thr68), pSTAT-3 (Tyr 705) and Chk1 (2G1D5) obtained from Cell Signaling Technology.

\section{Results}

\subsection{Coculture with adipocytes increases tumor cell survival and} enhances Chk1 activation after IR exposure

To characterize the possible effects of adipocytes on IR-induced cytotoxicity of tumor cells, we used the in vitro coculture system previously described [8]. Human cancer cells SUM159PT were grown for 3 days on inserts, allowing the diffusion of soluble factors, in the presence or not of mature adipocytes obtained from the in vitro differentiation of the murine preadipocyte cell line 3T3F442A [18]. After this incubation period, cells were irradiated and further incubated for $48 \mathrm{~h}$. The survival fractions after IR exposure of SUM159PT cells previously co-cultivated or not with mature adipocytes were determined by clonogenic assays. As shown in Fig. 1, coculture with adipocytes significantly decreased IR-cytotoxicity in tumor cells (survival fraction at $2 \mathrm{~Gy}, \mathrm{SF}_{2}=0.312$ when tumor cells were not co-cultivated, $\mathrm{SF}_{2}=0.57$ when cells were cocultivated with mature adipocytes, $p<0.001$ ). We next examined the phosphorylation pattern of the two effector kinases Chk 1 and Chk2 in these cells. As shown in Fig. 2A, a higher and earlier (see after $8 \mathrm{~h}$ ) increase in Chk1 phosphorylation was observed in irradiated SUM159PT cells that have been previously cocultivated with adipocytes as compared to tumor cells grown alone. Note that the level of expression of Chk1 remains constant between the two different culture conditions and was not affected by irradiation. By contrast, the level of Chk2 phosphorylation after IR exposure was not affected by the coculture. Given that irradiation-induced DNA double-strand breaks leads to chromosomal rearrangements, mitotic catastrophe, and ultimately to mitotic cell

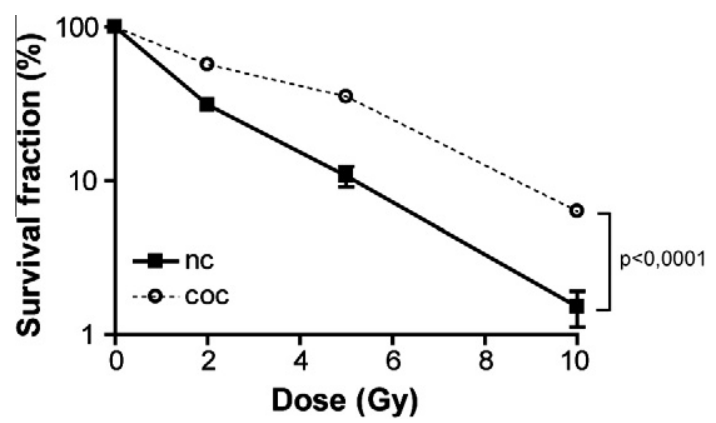

Fig. 1. Coculture with adipocytes improves SUM159PT survival after irradiation. Survival curves of irradiated SUM159PT cells cocultivated or not in the presence of mature adipocytes. After 3 days of co-cultivated ( $\mathrm{coc}$ ) or not (nc), tumor cells alone or tumor cells with adipocytes were irradiated with $0,2,5$ and $10 \mathrm{~Gy}$ and clonogenic assay was performed $48 \mathrm{~h}$ later. Data represent the mean of three independent experiments $\pm S D$, statistically significant by two-way ANOVA, $p<0.0001$. 


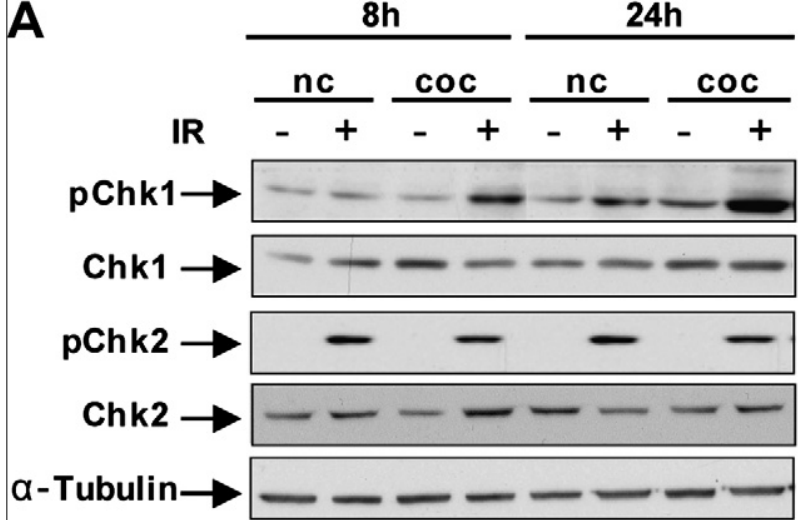

B Not irradiated
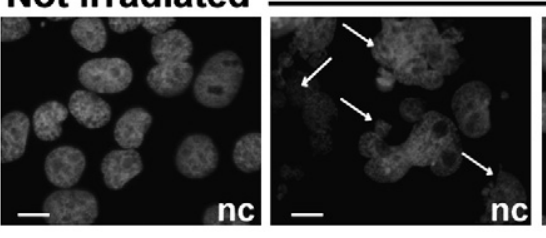

Irradiated

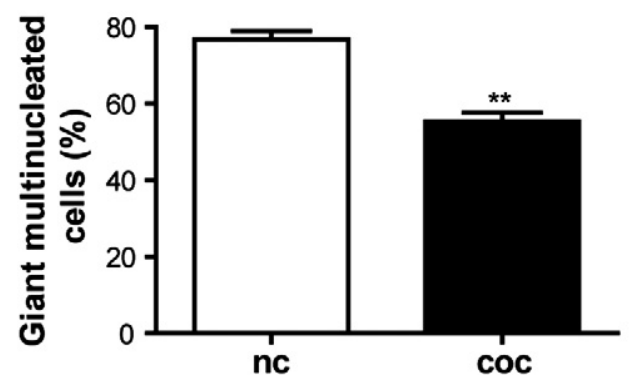

Fig. 2. Coculture with adipocytes enhances Chk1 activation after irradiation. (A) Western blot analysis of Chk1 and Chk2 phosphorylation. SUM159PT tumor cells were co-cultivated (coc) or not (nc) for 3 days and irradiated or not with $5 \mathrm{~Gy}$. Eight and $24 \mathrm{~h}$ after irradiation, cells were lysed and subjected to Western blot analysis with the indicated antibodies. All blots shown are representative of three independent experiments. (B) Multinucleated analysis of SUM159PT cells cocultivated or not before exposure to IR. Cells were grown during 3 days with (coc) or without (nc) adipocytes then exposed or not to $5 \mathrm{~Gy}$ irradiation and stained with DAPI $96 \mathrm{~h}$ after IR exposure. Upper panel: representative images of nuclei in each condition. Arrows indicate giant multinucleated cells. Scale bar $10 \mu \mathrm{m}$. Lower panel: histogram representing the percentage of multinucleated cells after irradiation of SUM159PT cells cocultivated (coc) or not (nc) with adipocytes prior to irradiation. Each bar represents more than 100 nuclei counted. Data represent the mean of at least three different experiments \pm SD, statistically significant by Student's $t$-test, ${ }^{* *} p<0.01$.

death, the appearance of giant multinucleated cells can be measured as a way to quantify cells undergoing mitotic cell death due to irradiation [15]. We therefore quantified the occurrence of giant multinucleated cells $96 \mathrm{~h}$ after exposure to $5 \mathrm{~Gy}$ irradiation. Indeed, as shown in Fig. 2B, there was an approximately 2 -fold decrease in the percentage of occurring giant multinucleated cells $(p<0.01)$ in adipocytes-co-cultivated cells as compared to tumor cells grown alone. Taken together, these compelling results show that adipocytes protect tumor cells from IR toxicity by preventing mitotic cell death through the induction of molecular factors important for the regulation of this pathway such as Chk1, as previously described $[19,20]$.

\subsection{The putative role of IL-6, secreted by tumor cells, in radioresistance}

Having described the effects of adipocytes on IR-induced cytotoxicity of tumor cell, we wanted to further understand the

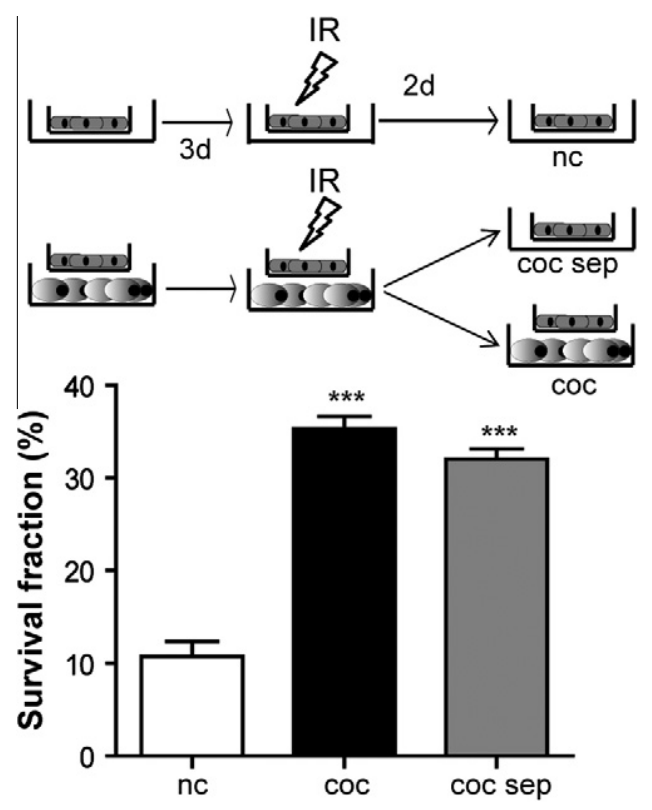

Fig. 3. Coculture with adipocytes induces tumor changes that confer intrinsic tumor cells radioresistance. Upper panel: experimental design: SUM159PT tumor cells were co-cultivated or not (nc) with mature adipocytes and irradiated or not with $5 \mathrm{~Gy}$. Then, co-cultivated cells are either further incubated with adipocytes ( $\operatorname{coc}$ ), or cultivated alone (coc sep). Forty-eight hours after irradiation, clonogenic assays were performed on tumor cells. Lower panel: histogram representing the survival fraction from the clonogenic assays analysis. Data represent the mean of at least three different experiments $\pm S D$, statistically significant by Student's $t$-test, ${ }^{* * * *} p<0.001$.

establishment of tumor cell radioresistance using our in vitro coculture system. We first investigated whether the presence of adipocytes within the first $48 \mathrm{~h}$ following exposure to IR was necessary to observe the radioprotective effect. Accordingly, previously co-cultivated tumor cells were irradiated and post-incubated for $48 \mathrm{~h}$ in the presence or not of adipocytes. Tumor cells grown alone in inserts during the entire time of the experiment were used as a negative control. The experimental design of these experiments is recapitulated in Fig. 3 (upper panel). As shown in Fig. 3 (lower panel), we found that while co-cultivated tumor cells were protected from IR-induced cell death, this effect was independent of the presence of adipocytes in the post-treatment period. These results demonstrate that the radioprotective effect is conferred by the changes induced in tumor cells by the coculture period prior to irradiation. According to the emerging role of inflammatory cytokines in the response of tumors to RT [21], we performed an extensive search for cytokines expressed by tumor cells after 3 days of coculture with adipocytes using qPCR analysis. Among the cytokines examined, we observed an exclusive 3-fold increase in IL-6 mRNA expression (Fig 4A, left panel $p<0.01$ ), whereas that of IL-1 $\beta$ or TNF $\alpha$ was not significantly affected (data not shown). ELISA experiment revealed that IL-6 secretion was undetectable when tumor cells were not co-cultivated, whereas the level of IL-6 secreted reached $2.5 \pm 0.05 \mathrm{ng} / \mathrm{ml}$ (mean of three independent experiments) when tumor cells were co-cultivated with mature adipocytes for 3 days. Furthermore, the incubation of SUM159PT cells with IL-6 after irradiation led to an enhanced Chk1, but not Chk2, phosphorylation similar to that of signal transducer and activator of transcription (STAT)-3, reflecting IL-6-specific activity (Fig. 4A, right panel). We then decided to test the direct effects of this important cytokine in conferring radioresistance to tumor cells in our model. As a matter of fact, when irradiated SUM159PT cells where post-incubated with IL-6 at $2.5 \mathrm{ng} / \mathrm{ml}$ and $30 \mathrm{ng} / \mathrm{ml}$, a dosedependant increase in the surviving fraction was observed as com- 

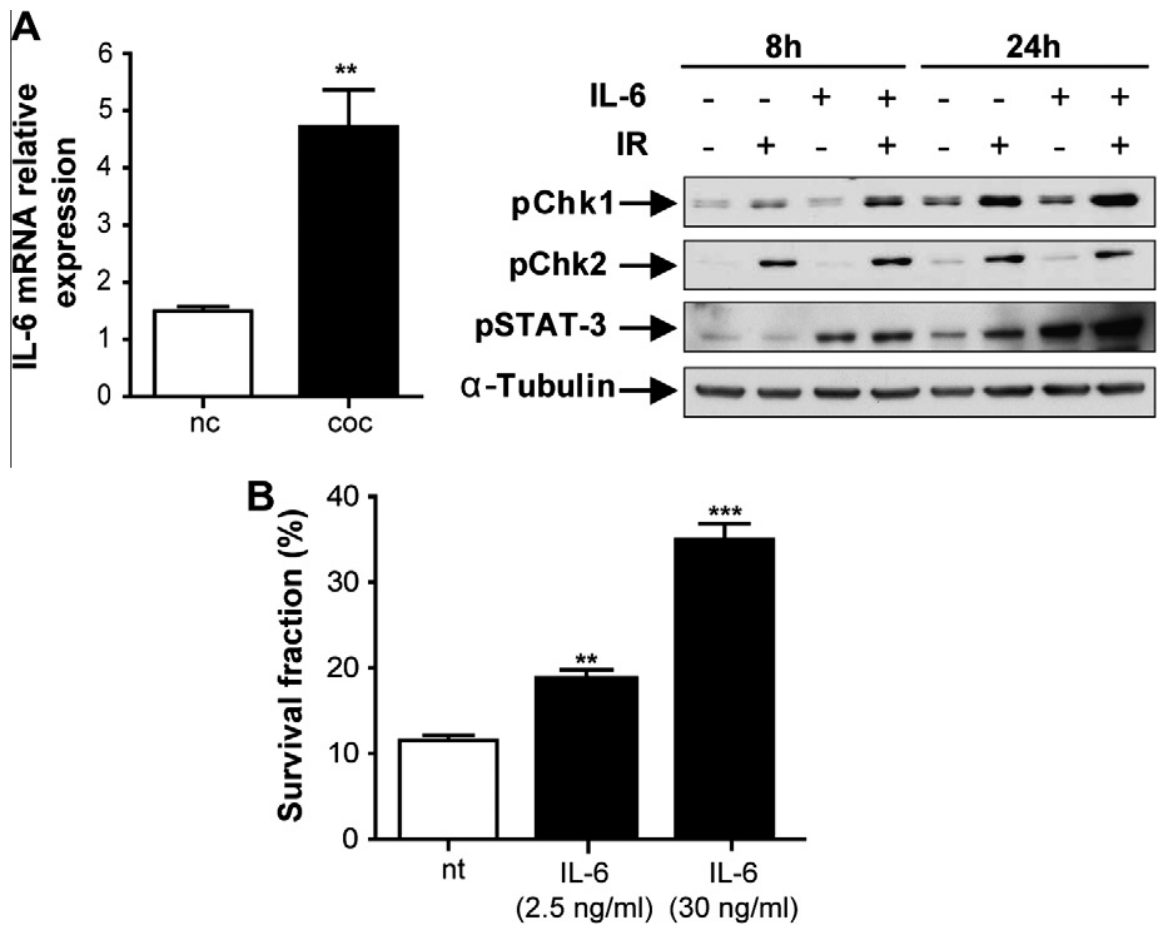

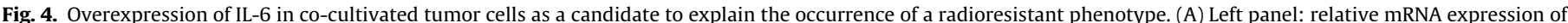

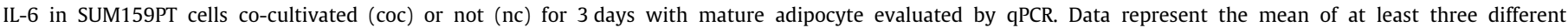

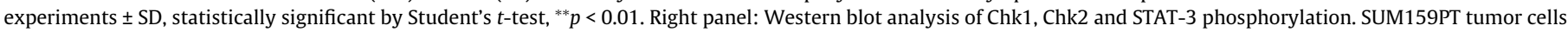

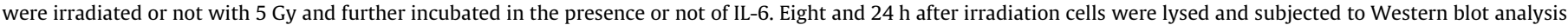

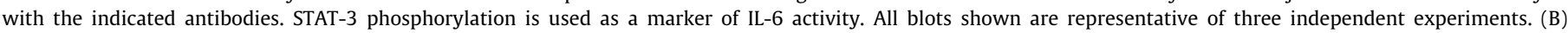

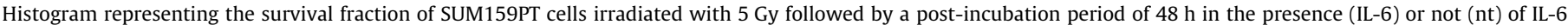
measured by clonogenic assay. Data represent the mean of at least three different experiments \pm SD, statistically significant by Student's $t$-test, ${ }^{* * *} p<0.001$.

pared to untreated cells (Fig. $4 \mathrm{~B}, p<0.01$ at $2.5 \mathrm{ng} / \mathrm{ml}, p<0.001$ at $30 \mathrm{ng} / \mathrm{ml}$ ). Altogether, these results suggest that IL-6 expression in tumor cells, induced by the cross-talk with adipocytes, might play a role in their acquisition of radioresistance.

\section{Discussion}

Several studies have demonstrated that the stroma (including endothelial cells, fibroblasts or macrophages) could cooperate to modulate the response of tumors cells to radiation exposure [913]. In this context, little attention has been given to the mature adipocytes, although it is obvious that they represent the most prominent cell type in breast tumor stroma. In the first part of our study we demonstrated that breast cancer cells co-cultivated with mature adipocytes exhibit both a decreased in IR sensitivity and post-mitotic cell death (see Figs. 1 and $2 \mathrm{~B}$ ), highlighting the role of adipocytes in fostering breast tumor cell radioresistance. Interestingly, adipocytes-induced tumor changes during the coculture time that precedes exposure to IR were the key determinant of the observed effect (see Fig. 3). These results suggest that tumorsurrounding adipocytes are able to induce inherent resistance in tumor cells rather that contributing to transient induction of protective pathways following radiation exposure, in opposition to stromal fibroblasts that confer radioresistance to breast tumor cells through the release of soluble factors [10]. This effect of adipocytes might not be limited to IR amongst the strategies used to treat cancer. In fact, it has been recently demonstrated that adipocytes prevented chemotherapy-induced apoptosis in leukemia, and this was associated with the increased expression of two prosurvival signals Bcl-2 and Pim-2 in leukemia-co-cultivated cells [22]. Among the cytokines secreted by tumor cells, we identified IL-6 as a good can- didate to confer, in an autocrine fashion, a radioresistant phenotype to tumor cells. First, IL-6 was overexpressed in co-cultivated cells as compared to cells grown alone (Fig. 4A). Secondly, the post-incubation of irradiated tumor cells with recombinant IL-6 was able to reproduce the radioprotective effect, in a dose dependent manner (Fig. 4B). There is accumulating evidence in the literature that inflammatory signaling pathways modulate the response of tumors to RT [21]. In contrast to other cytokines, few studies have involved IL-6 in radioresistance [23,13,24-27]. IL-6 activates several intracellular signaling pathways. Binding of IL-6 to its receptor activates the Janus family of kinases (JAK1, JAK2, and TYK2) and these kinases phosphorylate STAT-3, promoting its nuclear transfer and transcriptional function [28]. Interestingly, STAT-3 activation, by its ability to promote the expression in prosurvival genes such as survivin and bcl-X, has also been involved in radioresistance [29]. Our current study suggests that the increase in Chk1 phosphorylation might be involved in the observed radioresistant phenotype (see Figs. 2A and 4A). Previous studies linked Chk1 activity and cell survival after IR exposure. Its depletion triggers an important radiosensitive effect mainly due to aberrant mitosis $[19,20]$ whereas increased levels of phosphorylated Chk1 are associated to both chemo-and radioresistance [30,31]. Interestingly, a recent paper by Jin and colleagues demonstrated that in cells treated with cytokines (e.g. IL-3 or EPO), the increase in Chk1 phosphorylation, triggered by the activation of the Akt/ GSK3 pathway, contributed to the occurrence of a chemoresistant phenotype [31]. In our model, additional experiments are needed to decipher the signaling pathways involved, since IL- 6 is also able to activate the phosphoinositol 3 kinase (PI3K)-protein kinase B (PkB/Akt) pathway, as JAK can phosphorylate PI3K [32]. In conclusion, our work demonstrates for the first time, a role for tumor-surrounding adipocytes in fostering radioresistance in tumor cells. 
This work paves the way for future cellular studies aimed at determining the molecular mechanism involved and the impact of this new crosstalk in obesity conditions. Such studies will provide unique opportunities to set-up specific strategies for the treatment of the subsets of patients exhibiting aggressive diseases.

\section{Acknowledgments}

The authors would like to thank Dr. Geanncarlo Lugo for critical reading of the manuscript. The "Canceropole Grand Sud-Ouest" (to B.S., C.M.), La Ligue Nationale contre le Cancer (Equipe Labélisée to BS), INCA (to P.V., C.M.), The "Ligue Nationale Contre le Cancer (Comité "Midi-Pyrénées, Gers et du Lot" to C.M.) and the radioprotection Committee of EDF (to C.M.) supported this work.

\section{References}

[1] B.G. Haffty, P.M. Glazer, Molecular markers in clinical radiation oncology, Oncogene 22 (2003) 5915-5925.

[2] S. Ashwell, J.W. Janetka, S. Zabludoff, Keeping checkpoint kinases in line: new selective inhibitors in clinical trials, Expert Opin. Investig. Drugs 17 (2008) 1331-1340.

[3] G.M. Ross, Induction of cell death by radiotherapy, Endocr. Relat. Cancer 6 (1999) 41-44.

[4] M.M. Mueller, N.E. Fusenig, Friends or foes - bipolar effects of the tumour stroma in cancer, Nat. Rev. Cancer 4 (2004) 839-849.

[5] B.S. Wiseman, Z. Werb, Stromal effects on mammary gland development and breast cancer, Science 296 (2002) 1046-1049.

[6] M.W. Rajala, P.E. Scherer, Minireview: the adipocyte - at the crossroads of energy homeostasis, inflammation, and atherosclerosis, Endocrinology 144 (2003) 3765-3773.

[7] B. Dirat, L. Bochet, G. Escourrou, P. Valet, C. Muller, Unraveling the obesity and breast cancer links: a role for cancer-associated adipocytes?, Endocr Dev. 19 (2010) 45-52.

[8] B. Dirat, L. Bochet, M. Dabek, D. Daviaud, S. Dauvillier, B. Majed, Y.Y. Wang, A Meulle, B. Salles, S. Le Gonidec, I. Garrido, G. Escourrou, P. Valet, C. Muller, Cancer-associated adipocytes exhibit an activated phenotype and contribute to breast cancer invasion, Cancer Res. 71 (2011) 2455-2465.

[9] M.H. Barcellos-Hoff, S.A. Ravani, Irradiated mammary gland stroma promotes the expression of tumorigenic potential by unirradiated epithelial cells, Cancer Res. 60 (2000) 1254-1260.

[10] K.K. Tsai, J. Stuart, Y.Y. Chuang, J.B. Little, Z.M. Yuan, Low-dose radiationinduced senescent stromal fibroblasts render nearby breast cancer cells radioresistant, Radiat. Res. 172 (2009) 306-313.

[11] M. Garcia-Barros, F. Paris, C. Cordon-Cardo, D. Lyden, S. Rafii, A. HaimovitzFriedman, Z. Fuks, R. Kolesnick, Tumor response to radiotherapy regulated by endothelial cell apoptosis, Science 300 (2003) 1155-1159.

[12] F. Paris, Z. Fuks, A. Kang, P. Capodieci, G. Juan, D. Ehleiter, A. HaimovitzFriedman, C. Cordon-Cardo, R. Kolesnick, Endothelial apoptosis as the primary lesion initiating intestinal radiation damage in mice, Science 293 (2001) 293297.

[13] Y. Meng, M.A. Beckett, H. Liang, H.J. Mauceri, N. van Rooijen, K.S. Cohen, R.R. Weichselbaum, Blockade of tumor necrosis factor alpha signaling in tumorassociated macrophages as a radiosensitizing strategy, Cancer Res. 70 (2010) 1534-1543.
[14] A. Meulle, B. Salles, D. Daviaud, P. Valet, C. Muller, Positive regulation of DNA double strand break repair activity during differentiation of long life span cells: the example of adipogenesis, PLoS ONE 3 (2008) e3345.

[15] M. Castedo, J.L. Perfettini, T. Roumier, K. Andreau, R. Medema, G. Kroemer, Cell death by mitotic catastrophe: a molecular definition, Oncogene 23 (2004) 2825-2837.

[16] D. Daviaud, J. Boucher, S. Gesta, C. Dray, C. Guigne, D. Quilliot, A. Ayav, O. Ziegler, C. Carpene, J.S. Saulnier-Blache, P. Valet, I. Castan-Laurell, TNFalpha up-regulates apelin expression in human and mouse adipose tissue, FASEB J. 20 (2006) 1528-1530.

[17] F. Bouquet, C. Muller, B. Salles, The loss of gammaH2AX signal is a marker of DNA double strand breaks repair only at low levels of DNA damage, Cell Cycle 5 (2006) 1116-1122.

[18] H. Green, O. Kehinde, Spontaneous heritable changes leading to increased adipose conversion in 3 T3 cells, Cell 7 (1976) 105-113.

[19] Y. Tao, C. Leteur, C. Yang, P. Zhang, M. Castedo, A. Pierre, R.M. Golsteyn, J Bourhis, G. Kroemer, E. Deutsch, Radiosensitization by Chir-124, a selective CHK1 inhibitor: effects of p53 and cell cycle checkpoints, Cell Cycle 8 (2009) 1196-1205.

[20] H. Niida, Y. Katsuno, B. Banerjee, M.P. Hande, M. Nakanishi, Specific role of Chk1 phosphorylations in cell survival and checkpoint activation, Mol. Cell. Biol. 27 (2007) 2572-2581.

[21] A. Deorukhkar, S. Krishnan, Targeting inflammatory pathways for tumor radiosensitization, Biochem. Pharmacol. 80 (2010) 1904-1914.

[22] J.W. Behan, J.P. Yun, M.P. Proektor, E.A. Ehsanipour, A. Arutyunyan, A.S. Moses, V.I. Avramis, S.G. Louie, A. Butturini, N. Heisterkamp, S.D. Mittelman, Adipocytes impair leukemia treatment in mice, Cancer Res. 69 (2009) 78677874

[23] P.G. Braunschweiger, V. Basrur, O. Santos, A. Adessa, P. Houdek, A.M. Markoe, Radioresistance in murine solid tumors induced by interleukin-1, Radiat. Res. 145 (1996) 150-156.

[24] R.F. Hwang, T. Moore, T. Arumugam, V. Ramachandran, K.D. Amos, A. Rivera, B Ji, D.B. Evans, C.D. Logsdon, Cancer-associated stromal fibroblasts promote pancreatic tumor progression, Cancer Res. 68 (2008) 918-926.

[25] R. Neta, R. Perlstein, S.N. Vogel, G.D. Ledney, J. Abrams, Role of interleukin 6 (IL-6) in protection from lethal irradiation and in endocrine responses to IL-1 and tumor necrosis factor, J. Exp. Med. 175 (1992) 689-694.

[26] J.J. Dubost, C. Rolhion, A. Tchirkov, S. Bertrand, J. Chassagne, A. Dosgilbert, P. Verrelle, Interleukin-6-producing cells in a human glioblastoma cell line are not affected by ionizing radiation, J. Neurooncol. 56 (2002) 29-34.

[27] E.V. Efimova, H. Liang, S.P. Pitroda, E. Labay, T.E. Darga, V. Levina, A. Lokshin, B. Roizman, R.R. Weichselbaum, N.N. Khodarev, Radioresistance of Stat1 overexpressing tumour cells is associated with suppressed apoptotic response to cytotoxic agents and increased IL6-IL8 signalling, Int. J. Radiat. Biol. 85 (2009) 421-431.

[28] P.J. Murray, The JAK-STAT signaling pathway: input and output integration, J. Immunol. 178 (2007) 2623-2629.

[29] B.B. Aggarwal, A.B. Kunnumakkara, K.B. Harikumar, S.R. Gupta, S.T. Tharakan, C. Koca, S. Dey, B. Sung, Signal transducer and activator of transcription-3, inflammation, and cancer: how intimate is the relationship?, Ann N. Y. Acad. Sci. 1171 (2009) 59-76.

[30] B. Hu, X.Y. Zhou, X. Wang, Z.C. Zeng, G. Iliakis, Y. Wang, The radioresistance to killing of A1-5 cells derives from activation of the Chk1 pathway, J. Biol. Chem. 276 (2001) 17693-17698.

[31] Z.H. Jin, T. Kurosu, M. Yamaguchi, A. Arai, O. Miura, Hematopoietic cytokines enhance Chk1-dependent G2/M checkpoint activation by etoposide through the Akt/GSK3 pathway to inhibit apoptosis, Oncogene 24 (2005) 1973-1981.

[32] J. Zhang, Y. Choi, B. Mavromatis, A. Lichtenstein, W. Li, Preferential killing of PTEN-null myelomas by PI3K inhibitors through Akt pathway, Oncogene 22 (2003) 6289-6295. 